\title{
HOW TO DO IT? COMMUNICATION FOR MANAGING CAFE IN PEKALONGAN
}

\author{
Irmawan Rahyadi, Riyanto Jayadi, Hanggoro Pamungkas \\ Bina Nusantara University, Indonesia. \\ irmawan.rahyadi@binus.edu
}

\begin{abstract}
Communication in cafe between workers serving customers shaped according to a system set preliminary to launching the space. Communication in order to deliver orders to service table is challenged when certain scenarios introduce to the dynamics between workers. This article discusses the view of communication for managing cafe in Pekalongan. The skills involved in managing cafe include cashier application system, simple accounting and tax. Communication as an integral part which intertwined all the cashier, waiter, cook and customer in routine process of a cafe. Today, cafe flourishing all over Indonesia including some rural part of the country encourage skills to be adapted by managing party to run day to day activities. Pekalongan with its natural assets opens opportunities to bring up human assets especially youth and productive age level in rural Indonesia. Descriptive case study is applied in this article where a small group of trainees of youth and PKK members observed as sample. In order to understand how management cafe can be instilled as an applicable skill, community development project in Pekalongan is studied. This article revealed supporting findings to contribute to practical and academic conversation which shows that certain scenarios exercises beneficial in comprehension of communication between cafe personnel and customers. This insight gave us a clearer portrait of how communication is an essential part of workplace positive dynamics especially when external stakeholders are involved in the communication process.
\end{abstract}

Keywords: Communication, Cafe, Management, Cashier Application, Accounting

\section{INTRODUCTION}

Food service industry in Indonesia hits the spot as a favorite choice for entrepreneurship journey while it also contributed about \$22,1 billions to GDP (McDonald \& Yuningsih, 2019). Walking down the street of urban and rural area in the country, one could easily notice how food service industry particularly small restaurant, street-side restaurant and street vendor dominated the domain. Cafe, on the other hand, introduced to the country as an alternative and newer food consumption service. This industry provides to consumer eating food not only as necessity but also as a whole new experience. The experiences sold as a new package starting from customer open the door to the cafe where comfortable seating, cool airconditioner space, and Wi-Fi access accompanied customer to finish their food.

Owing to service element in this industry as well as relationship with customer as external stakeholder, food service has emerged as one of the most important industry in Indonesia during the past year. Focusing on history of cafe familiarization in Indonesia, cafe started as franchise fast food restaurants set a new standard of eating and dining experiences then continued by international coffee shop chains. The infiltration familiarized a simple drinking-coffee experience as trendy and updated way to express modern lifestyles. As consumers demand increases within food and drink consumption in cafe, motivational drivers can be linked to materialism and conformity which demand a better service from the industry (Kim and Jang, 2014).

Food service industry explicitly emphasizes on service to the customers as the main feature. No matter the level of industry scope, service is the most important thing in this business. Two distinct ways to distinguish between good service and bad service are serving more customers and efficient service (Thompson \& Kwortnik, 2008). This article described how to manage a cafe through a case study where community development in Pekalongan took place to tackle a lack of skills needed especially in communication aspect of managing a cafe in rural area.

Pekalongan is a city in Central Java where industries getting developed in many areas. With the population of 311 million people living in a $45 \mathrm{~km}$ square area, there is a potential human economic and community development to empowering local society (Susanto, 2019). A community development project from Bina Nusantara University aimed to empower the local society was targeted a BKM (Balai Keswadayaan Masyarakat) in Pekalongan. Setting up a cafe in Krapyak area near beach as an economic catalysator for people living in the neighborhood. The specific sub-project organized by a team from Communication, Information and Accounting will be discussed in this article tackling training to youth in the area of 
managing cafe.

\section{METHOD}

This article will describe how community development sub-project found revealing facts from the field that could benefit the practical and academic conversation. The method applied in this article is descriptive case study. This type of case study reflects telling a story behind what happen in the field to be presented in the formal level of academic literature. Differ from exploratory case study when exploratory digs deeper on field research and literature study, descriptive case study articulates implication of a case study and propositions along with questions about a phenomenon. While both offers no explanation and casual connection between variable, descriptive case study specifies boundary of the case pointed and contributes significantly to rigor the case (Mills et al., 2010).

Case study of training and delivering materials and tools to trainees in Pekalongan are described in this article.

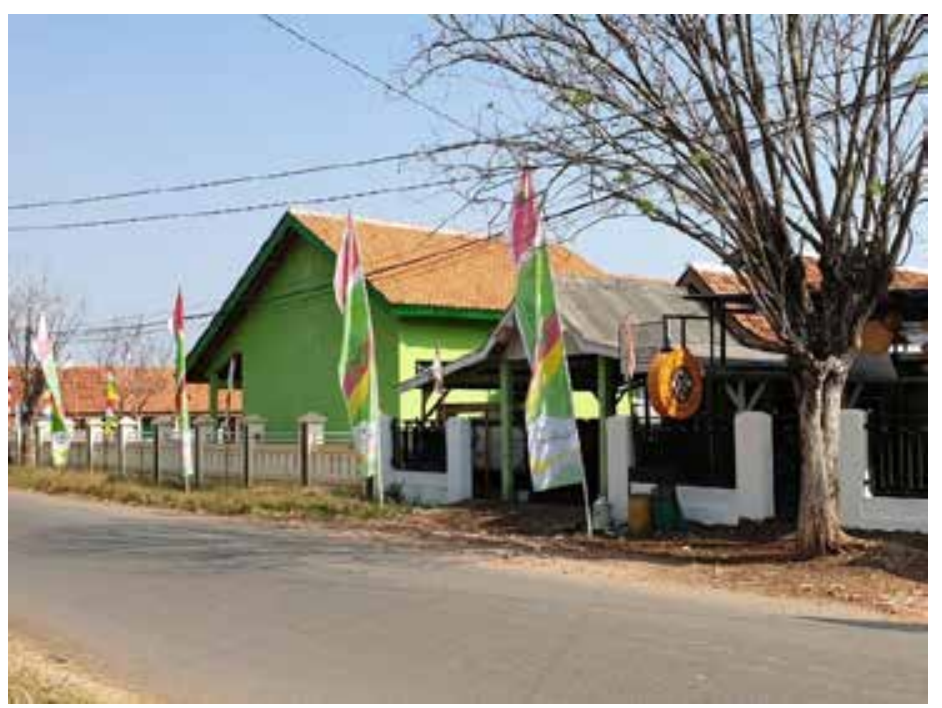

Figur 1. Cafe Location in Krapyak, Pekalongan.

The project takes place in Krapyak, Pekalongan, Central Java. This beach area is populated with a diversity of local with profession range from fisherman, workers, and farmer. The idea behind this project is to contribute to people' welfare in the area by assisting setting up a cafe as entrepreneurship endeavor for locals to utilize and express their resources for economical improvement. The cafe is called "Omah Jlamprang" captivating local wisdom into the name as local Batik pattern brand. The cafe set with modern-rustic design but selling local food and drink with a twist of local ingredients such as Es Kelapa Alang-Alang and Begono Gulung.

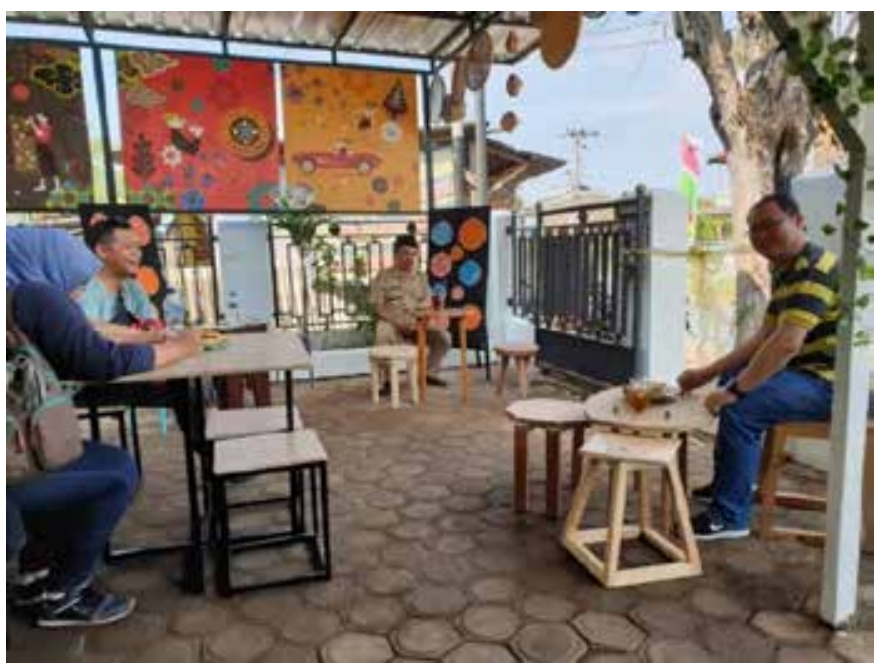

Figur 2. Interior design of Omah Jlamprang. 
Empowering the resources of the locals, Bina Nusantara University team assisted in specific areas while our team supported an area where communication, IT and accounting skill are trained to manage the cafe. Trainees mostly age within productive age level which benefit the project to be sustainable in the long run. There are some ladies as participants from the Family Welfare Movement (PKK). There are 15 trainees who will manage the cafe in set of routine designed as a small space. Communication for managing cafe started with in-class briefing and training-material sharing. Communication materials such as "What, Who and How" as the communication tool delivered in class. One of team member from Information Technology gave hands-on training on cashier application on Android. The next area in the training material is accounting and tax. The training was conducted in BKM building under management by district of Krapyak, Pekalongan where Cafe Omah Jlamprang located.

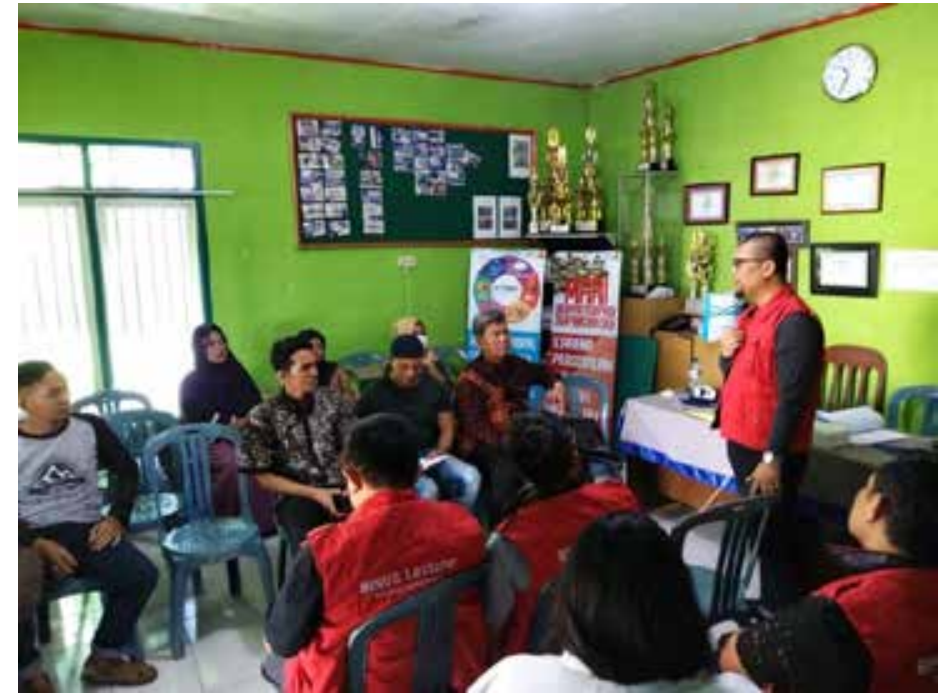

Figur 3. Training for locals in BKM Krapyak.

\section{RESULTS AND DISCUSSIONS}

Training was conducted in three days. Team member focusing in communication skill gave in-class training featuring "What" aspect to be comprehended by managing personnel in the cafe. It covers product knowledge, space and vision behind the cafe. The next element in the mix to be successful in communication for managing cafe is "Who". Getting to know all the personnel who one works with is the key of manageable dynamic in a cafe. The cafe serves food from many tenants regulating in rotation, resulting in getting to know all the tenant in person important to perform better service to customers. Knowing customers also highlighted to accomplish better service. The method of delivery from trainer is to emphasize customer knowledge by encouraging discussion considering trainees know potential costumers better than the trainers. The last element in the communication-mix to managing cafe is "How'. How to manage cafe in small space and scale is deliver as cases and scenarios-based delivery in class. Material delivered to trainees was derived from contemporary academic and professional conversation. The training material is purposively designed for the trainees. It supports what has mentioned in academic literature that concluded any purpose of training material has to defined in the first stage (Douglas et al., 2018).

Team member from Information System field gave training in cashier management. Third-party application in Android-based mobile format was used as software cashier machine. The team in this community development project donated an Android tablet along with cash-register printer with thermal heat processing. Hands-on training for smaller group and one-on-one delivery was organized for cash register training. Hands-on training qualitative and quantitative parameters in participant and performance of training (Noureldin et al., 2019). This type of training more targeted to getting to know how to operate the application on the first day. On the second and third days, trainees presented with scenarios of cashier operating beyond machine application. Scenarios include how cashiers handle orders when cafe condition in rush hours, cafe in slow condition, transfer between cashier in shift, and when cafe closing.

For skills in accounting and tax, team member as an expert in this area prepared material covering two aspects namely, administration-financial-accounting and state obligation-tax. Cafe management advised to record all financial capital, cash-flow, debit/credit, inventory/equipment and merchandise in daily, 
monthly and yearly term, making sure recording process done neatly and structured. Spread sheet for profit-loss balance report, daily-monthly diary, and end-of-year report was introduced as a sample and template to initiate routine cash management in the cafe. Tax management skills cover areas from taxpayers' obligation for small cafe, NPWP, PPN, PKP, to SPT (annual tax return forms) submission underlining cafe management awareness of this area to avoid fines in the future.

\section{CONCLUSION}

While revenue management mentioned as food industry focus in pricing and marketing strategies, management of cafe focusing in service surfaced as an importance scale directed towards getting customers satisfaction (Lee \& Ok, 2013; Rowson et al., 2016; Tse \& Poon, 2016). Service to customers is important in getting feed back and well-being of customers, on the other hand, service failures in this industry decrease brand. (Kandampully, 2014; Khan et al., 2015; Norvell et al., 2018). To achieve good service management, training is essential in the early stage of setting up a cafe.

Training to personnel in this article targeted to prepare communication for managing cafe. The process has revealed that discussing scenarios in relating to customers in business setting resulting in more elaborated material comprehension. Understanding different scenarios supposedly happen in routine operation give personnel a book of guidance to handle the situation without resulting in service failures. Before customer generate a belief about any type of service failures, personnel need to communicate among themselves aiming for improvement of service (Vaerenberg et al., 2014). On the different note, communication between customer and personnel derived from understanding of element in communication mix where skills trained and improved regularly. Future direction to recommend for community development project in the areas are interdisciplinary field teams and scenarios-based delivery into training materials.

\section{REFERENCES}

Douglas, S., Uitto, D., Reinfelds, C., and D’Agostino. (2018). “A systematic review of paraprofessional training materials. The Journal of Special Education, Vol. 52:4, 195-207.

Kandampully, J., Keating, B., Kim, B., Mattila, A. and Solnet, D. (2014). "Service research in the hospitality literature: Insights from a systematic review". Cornell Hospitality Quarterly. Vol. 55:3. 287-299.

Khan, M., Ro, H., Gregory, A., and Hara, T. (2015). ”Gender dynamics from an Arab perspective: Intercultural service encounters". Cornell Hospitality Quarterly, Vol. 57:1. 51-65.

Kim, D. and Jang, S. (2014). "Symbolic consumption in upscale cafes: Examining Korean gen Y consumers' materialism, conformity, conspicuous tendencies, and functional qualities". Journal of Hospitality \& Tourism Research, Vol. 41:2, 154-179.

Lee, J., and Ok, C. (2013). " Examination of factors affecting hotel employees' service orientation: An emotional labor perspective". Journal of Hospitality and Tourism Research, Vol. 39:4, 437-468.

McDonald, G and Yuningsih, N. (2019). Indonesia food service - Hotel restaurant institutional. Hotel restaurant institutional update. USDA Foreign Agriculture Service, Jakarta.

Mills, A., Europes, G., and Wiebe, E. (2010). Encyclopedia of Case Study. Sage Publication, California.

Norvell, T., Kumar, P., and Dass, M. (2018). "The long-term impact of service failure and recovery". Cornell Hospitality Quarterly, Vol. 59:4. 376-389.

Noureldin, Y., Hoening, D., Zhao, P., Elsamra, S., Stern, J., Gaunay, G., Motamedinia, Okeke, Z., Rastinedad, A., and Sweet., R. (2019). "Incorporation of the fluoroless C-Arm trainer at the American Urological Association hands-on training of percutaneous renal access: Pilot study". Arab Journal of Urology, Vol. 16, S3.

Rowson, B., Poppel, W., and Gehrels, S. (2016). "Wasted millions: Revenue management in Dutch culinary restaurants". Research in Hospitality Management, Vol. 6:2, 127-134

Susanto, B. (2019, August 13). Setiap hari, warga kota pekalongan buang 17,5 ton sampah tidak pada tempatnya. Tribunjateng.com. Retrieved from https://jateng.tribunnews.com/2019/08/13/setiap-hariwarga-kota-pekalongan-buang-175-ton-sampah-tidak-pada-tempatnya

Thompson, G. and Kwortnik. R. (2008). "Pooling restaurant reservations to increase service efficiency". Journal of Service Research, Vol. 10: 4, 335-346.

Tse, T., and Poon, Y. (2016)." Modeling no-shows, cancellations, overbooking, and walk-ins in restaurant revenue management”. Journal of Foodservice Business Research, Vol. 20, 127-145.

Vaerenberg, Y., Orsingher, C., Vermeir, I., and Lariviere, B. (2014). "A meta-analysis of relationships linking service failure attribution to customer outcomes". Journal of Service Research. Vol. 17:4. 381398. 